\title{
Incidence of Pancreatic Cancer Cases in Dr. Soedarso Hospital Pontianak
}

\author{
Dery Wahyudi ${ }^{1}$, Sari Eka Pratiwi ${ }^{2 *}$ \\ ${ }^{1}$ Faculty of Medicine, Tanjungpura University, Pontianak, Indonesia \\ 2 Department of Biology and Pathobiology, Faculty of Medicine, Tanjungpura University, Pontianak, Indonesia
}

\section{ARTICLE INFO}

Received : 30 October 2020

Reviewed : 13 November 2020

Accepted : 17 March 2021

Keywords:

cancer, incidence, pancreatic cancer, risk factors

\begin{abstract}
Background: Pancreatic cancer has a poor prognosis, and the symptoms are difficult to be detected early in the early stages. Indonesia Statistics on 2004-2007 states that pancreatic cancer is not included in the 10 cancers with the highest incidence. In West Kalimantan. There are no published data related to pancreatic cancer cases. This is the reason for the researchers because this data is sufficiently needed to support other studies related to pancreatic cancer.
\end{abstract}

\begin{abstract}
Methods: Epidemiological studies were conducted in the form of data collection at Dr. Soedarso Hospital Pontianak. Data were retrieved from cases of pancreatic cancer regression in annual Morbidity Data of Pancreatic Cancer Patients in Dr. Soedarso Hospital Pontianak from 2018 until 2009 consisting of the frequency of new cases and deaths, as well as demographic data such as age and gender of patients. Data were processed using Microsoft Excel.
\end{abstract}

Results: A total of 79 cases and 9 deaths caused by pancreatic cancer were recorded in Dr. Soedarso Hospital Pontianak from January 2009 to December 2018. The highest incidence rates occurred in 2014 with 17 out of 79 cases (21.5\%). As many as 63.3\% of pancreatic cancer cases are dominated by men. Most cases of pancreatic cancer in patients with the age range of 45-64 years $(67.1 \%)$ and the average age is 53.8 years.

Conclusions: Incidence of pancreatic cancer in Dr. Soedarso Hospital Pontianak each year of 7.9 cases. Men and elderly people dominate cases of pancreatic cancer. Further study of the clinical characteristics and analysis of risk factors in patients with pancreatic cancer needs to be done to support preventive strategy development.

\section{INTRODUCTION}

Cancer is a pathological condition arising due to the escape of cells from cell growth control mechanism so that the cancer cells can invade nearby structures to metastasize, which can lead to death [1]. An organ that can undergo pathological conditions such as cancer in the pancreas. The pancreas is an endocrine-exocrine organ with a retroperitoneal position and consists of caput (head), corpus (body), and cauda (tail) [2]. Pancreatic cancer is generally divided into two main types of pancreatic adenocarcinoma and pancreas neuroendocrine tumors and based on the clinical stage of the tumor, can be classified into four types of stages; they are stage I, stage II, stage III, and stage IV [3,4]. Pancreatic adenocarcinoma is a type of pancreatic cancer that attacks the exocrine glands with a high incidence rate, about $85 \%$ of cases with a bad prognosis. Only $24 \%$ of patients can survive for 1 year after diagnosis and approximately $9 \%$ of patients can survive for five years. Pancreatic neuroendocrine tumor/Pan-NET is a type of pancreatic cancer that wrecks the pancreatic endocrine tissue with an incidence rate of less than $5 \%$ $[3,5]$.

Pancreatic cancer has a poor prognosis due to various reasons. Generally, the patient realizes and is diagnosed when cancer has reached the advanced stage due to the difficulty of early detection of symptoms in the early stages [6]. Etiology and risk factors are associated with modifiable risk factors that include smoking tobacco [7], alcohol [8], obesity [9], dietary factors [10], and occupational exposure [11]. Whereas non-modifiable risk factors include gender, age, ethnicity, 
or race [12], diabetes mellitus [13], a family history of pancreatic cancer [14], and non-blood group O [15].

Based on estimates of GLOBOCAN 2018, pancreatic cancer ranks as the 11th most common cancer in the world with 458,918 new cases and 432,242 deaths (4.5\% of all deaths caused by cancer) in 2018. Data from The Age-Standardized Rate (ASR) reported the highest case rate in Europe $(7.7$ of 100,000$)$ with the highest prevalence by sex in men which numbered 5.5 out of 100,000 (243,000 cases) [16]. Indonesia Statistics on 2004-2007 states that pancreatic cancer is not included in the 10 cancers with the highest incidence [17]. The average age of patients with pancreatic cancer is influenced by many factors such as age, sex, cancer type, stage of diagnosis, tumor size, the level of albumin in serum, the care provided, health care systems, and other factors, including all aspects of health care and lifestyle $[18,19]$.

In West Kalimantan, there are no published data related to pancreatic cancer cases based on demographic characteristics such as age and gender, as well as incidence and mortality data. This is the reason for the researchers because this data is sufficiently needed to support other studies related to pancreatic cancer.

\section{METHODS}

Epidemiological studies were conducted in the form of data collection at Dr. Soedarso Hospital Pontianak from the Health Promotion Section Hospital through the approval of the Education and Research Section of Dr. Soedarso Hospital. Collecting data for pancreatic cancer cases referred to the International Classification of Diseases for Oncology (ICD-0) to the third edition illustrated with topography code C25 for all types of pancreatic cancer. Based on the medical record data on patients with pancreatic cancer cases in 2018 , it is known that the diagnosis of pancreatic cancer at Dr. Soedarso Hospital is also based on radiological examinations such as abdominal CT scans and abdominal ultrasound. Data in 2018 show that most of the therapies include symptomatic medication and surgery. Positive smoking status was also found in one of six patients in 2018 but it was negative for alcohol status. The data were retrieved from cases of pancreatic cancer regression in annual Morbidity Data of Pancreatic Cancer Patients in Dr. Soedarso Hospital Pontianak. Morbidity data consisting of the frequency of new cases and deaths, as well as demographic data such as age and gender of patients, were processed using Microsoft Excel. The study was not followed by the retrieval of medical records due to insufficient files of patient data for 2009-2016.

\section{RESULT}

A total of 79 cases of pancreatic cancer were recorded in Dr. Soedarso Hospital Pontianak from January 2009 to December 2018. Table 1 shows the demographic characteristics of pancreatic cancer patients' cases. Figure $\mathbf{1}$ shows the incidence of pancreatic cancer cases with the highest incidence rates in 2014, 17 out of 79 cases (21.5\%), and the lowest incidence rates in 2009, 3 out of 79 cases (3.8\%). The mean incidence of pancreatic cancer each year is 7.9 cases, followed by the gross death rate of $11.4 \%$, which means that from 2009 to 2018, 1,140 of the 10,000 patients survived. There were 9 deaths caused by pancreatic cancer throughout 2009-2018. The highest mortality rates occurred in 2016 with 3 deaths (30\%) of patients with pancreatic cancer. The incidence in the last decade is mostly above-average incidence, and the trend is increasing exponentially.

Table 1. Demographic characteristics of pancreatic cancer patients in Dr. Soedarso Hospital Pontianak from January 2009 to December 2018

\begin{tabular}{rlll}
\hline Characteristics & $\mathbf{N}=\mathbf{7 9}$ & $\%$ & Mean \pm SD \\
\hline Gender & & & \\
Male & 50 & 63.3 & - \\
Female & 29 & 36.7 & - \\
\hline Age (years) & & & \\
$15-24$ & 4 & 5.0 & \\
$25-44$ & 7 & 8.9 & $53.80 \pm 11.90$ \\
$45-64$ & 53 & 67.1 & \\
$65-74$ & 15 & 19.0 & \\
\hline
\end{tabular}

Pancreatic cancer cases at the Dr. Soedarso Hospital Pontianak throughout 2009-2018 as many as $63.3 \%$ are dominated by men while cases in women are only about a third of the total cases. The highest number of cases in men occurred in 2014 and women occurred in 2011, 2014, 2017, and 2018 (Figure 2).

The age range of most cases of pancreatic cancer at the Dr. Soedarso Hospital Pontianak is 45-64 years $(67.1 \%)$ and the average age is 53.8 years. The next highest age distribution is in the elderly (>65 years) with 15 cases (19\%) followed by 7 cases $(8.9 \%)$ at $25-44$ years and 4 cases $(5.0 \%)$ at $15-24$ years (Table 1 ).

Focusing on the medical record data of six patients with pancreatic cancer in 2018, it is known that the diagnosis of pancreatic cancer at Dr. Soedarso Hospital is also based on radiological examinations such as abdominal CT scans and abdominal ultrasound. Data in 2018 also show that the most common therapies are 
Figure 1. Incidence and mortality of pancreatic cancer cases in Dr. Soedarso Hospital Pontianak in a period of January 2009 to December 2018.

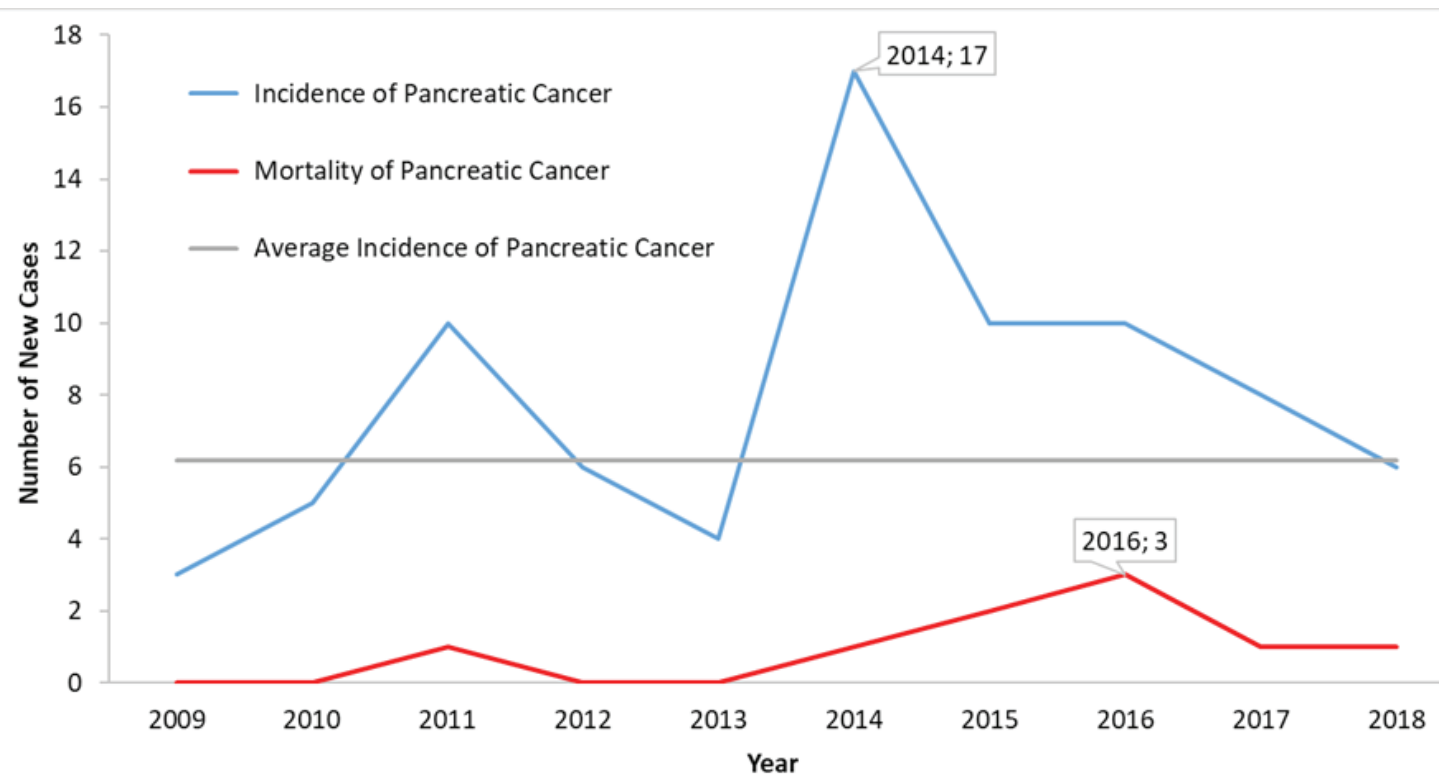

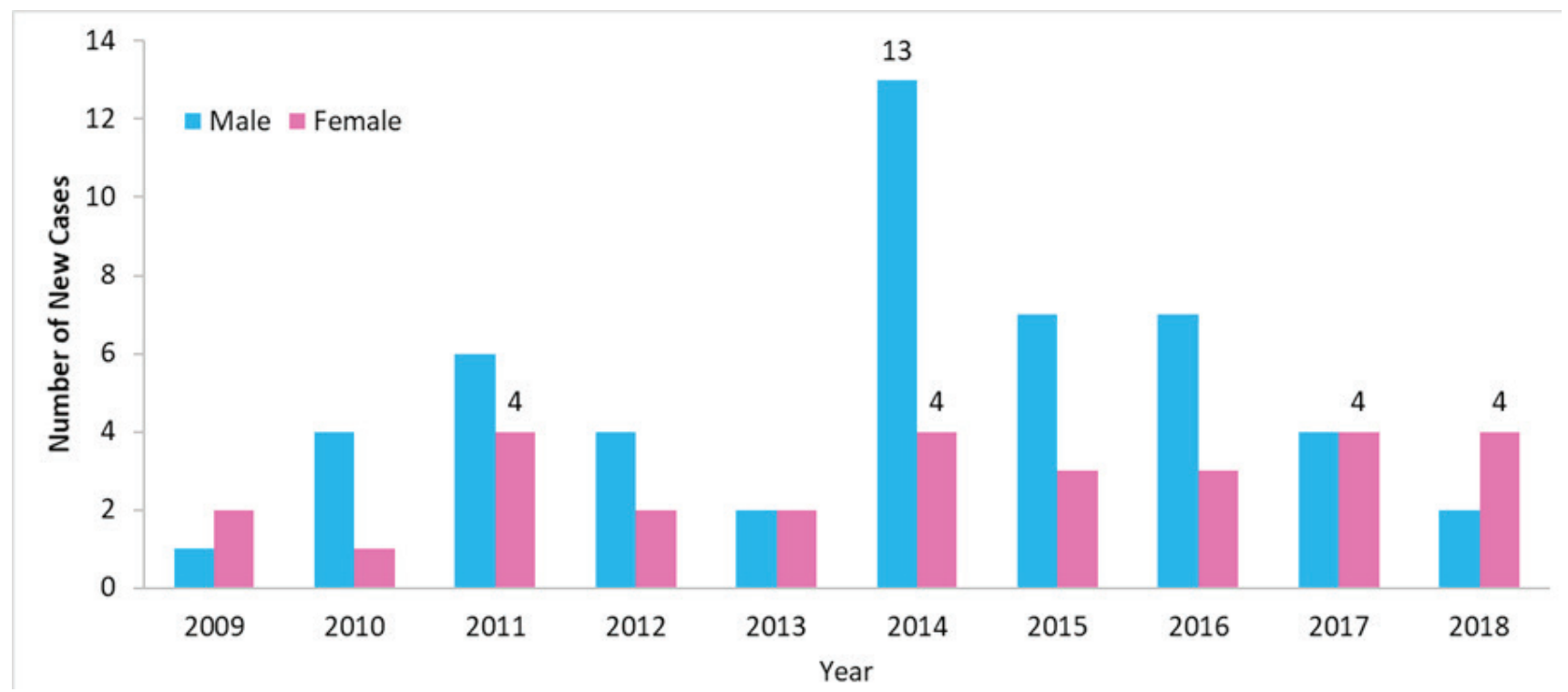

Figure 2. Sex distribution of pancreatic cancer patients in Dr. Soedarso Hospital Pontianak in a period of January 2009 to December 2018.

symptomatic medication and surgery. In addition, the 2018 data confirm that all patients are negative for alcohol but there is a positive smoking status in one of them.

\section{DISCUSSION}

The incidence of pancreatic cancer is not higher than that of other types of cancer but has a significant mortality rate in the world compared with other types of cancer due to the poor prognosis of this type. In 2012, IARC-GLOBOCAN reported several new cases in the world by 337,872 cases of pancreatic cancer with a mortality rate of 330,390 due to pancreatic cancer (97.78\%) [20]. In 2015, there were 367,000 new cases in the world reported with a mortality rate approaching the incidence rate of new cases. GLOBOCAN in 2018 reported that pancreatic cancer ranked 11th as common cancer with the incidence rate reaching 458,918 new cases, followed by 432,242 deaths in the world due to pancreatic cancer (94.18\%) [16].

Epidemiological studies linked pancreatic cancer conducted in Palembang showing that the incidence of pancreatic cancer is $0.05 \%$ of the total patients in the Inpatient Hospital Dr. Mohammad Hoesin in 2009-2013 [21]. Research conducted at the Hospital Dr. Wahidin Sudirohusodo Makassar in 2015-2017 reported that there were 79 cases of pancreatic cancer (1.4\%) from 5,824 total cases of all cancer types. The small incidence in previous studies in line with the number of cases of pancreatic cancer in this study is quite small when compared to the incidence of other types of cancer. The mortality rate $(16.2 \%)$ in this study was small when 
compared with that in the study in Makassar where a mortality rate is 22 deaths of 79 total cases of pancreatic cancer (30\%) [22]. The highest mortality rates in 2018 were reported globally in Western Europe (7.6 of 100,000), Eastern and Central Europe (7.3), as well as Northern Europe and North America (6.5), while the lowest mortality rates were reported in East Africa (1.4) as well as Southeast Asia and West Africa (2.1) [16].

GLOBOCAN 2018 reported the highest prevalence by sex was in men which amounted to 5.5 out of 100,000 (243,000 cases), while in women, it was 100,000 (215 885 cases) [16]. Men dominated. The results of this study showed $66.7 \%$ of the total number of pancreatic cancer cases in line with the results of previous studies in Palembang [21], Makassar [22], and Medan [23] which show that most pancreatic cancer patients are men. The highest risk of pancreatic cancer in men globally is in Eastern and Central Europe, especially in Latvia and the Republic of Moldova (15.3), Estonia (14.2), and Hungary (12.9), while the lowest average is in Guinea (0.23) and Malawi (0.30) [16]. Differences in the incidence rate of pancreatic cancer among men and women are not caused by reproductive factors [24] but the influence of environmental exposures such as lifestyle or genetic factors [25].

Men's lifestyle that becomes a risk factor for pancreatic cancer is cigarette smoking and alcohol consumption. According to Riskesdas 2018, the rate of tobacco consumption in Indonesia's population aged above 15 years, especially in males, is always 10 to 12 greater than that in women, and it becomes a major risk factor of pancreatic cancers in men [26]. Smokers have a two to three-fold pancreatic cancer risk level higher than non-smokers in which the proportion of pancreatic cancer cases caused by smoking is estimated as much as $15-30 \%$ in various populations. Case-control studies were conducted by comparing smokers and nonsmokers finding the odds ratio (OR) value of 1.2 on the people who had experience as smokers and OR value of 2.2 for inactive smokers [16]. A meta-analysis of 82 recent studies has also found the study results on the relative risk (RR) of pancreatic cancer and its relation with smoking with $R R=1.74$ for inactive smokers and $R R=1.2$ for those who had experience as smokers [27].

A total of 69 of 7,000 chemicals contained in tobacco smoke such as arsenic, benzene, beryllium, cadmium, chromium, ethylene oxide, nickel, polonium, vinyl chloride, formaldehyde, benzo $[\alpha]$ pyrene, and toluene are chemical carcinogens, which can lead to cancer [20]. Various studies show the fact that smoking is a major risk factor of pancreatic cancer where the evidence indicates that carcinogenic substances in tobacco smoke stimulate the progression of pancreatic cancer because of inflammation induction and fibrosis that influence genetic factors on cell death inhibition and stimulate proliferation [28]. The toxic effect of smoking tobacco carcinogenesis induced by genetic and epigenetic causes of alteration/deviation genes function as tumor suppressor genes, DNA repair, and cell cycle. Recent studies have focused on the cellular and molecular mechanisms of immune dysfunction by smoking tobacco [29].

The findings of some studies also suggested that the relationship between pancreatic cancer risk factors such as alcohol consumption habits is significantly more prevalent in males compared with females [30,31]. Heavy or excessive alcohol consumption by more than three cups per day is a habit that can increase the risk factor for pancreatic cancer and has been found in many studies but is not associated with low and medium-level alcohol consumption [8]. Linkage of alcohol consumption habits related to increased recurrent acute pancreatitis (RAP) and chronic pancreatitis risk factors associated with many studies become a significant risk factor of pancreatic cancer [12,32]. Some mechanisms of alcohol consumption become a risk factor of pancreatic cancer such as DNA damage caused by ethanol metabolism to acetaldehyde, producing reactive oxygen species, nutrition disruption nutrition (vitamin $A$, vitamin $B$ complex, vitamin $C$, vitamin $D$, vitamin $E$, dan carotenoid), carcinogenic contaminant product caused by fermentation effects like nitrosamines, asbestos fibers, phenol, and hydrocarbonate [33].

This study also shows that $62.60 \%$ of pancreatic cancer cases occur in the age of 45-64 years which indicates the peculiarities of pancreatic cancer in which statistically globally reports that the incidence of pancreatic cancer is identical with the elderly population. Similar results were described in previous studies in Palembang [21], Makassar [22], and Medan [23] which broadly describes the age distribution of pancreatic cancer patients at the age of more than 40 years or a range of 45- 60 years and rarely occurs at ages under 30 years. Pancreatic cancer is rarely diagnosed at ages under 55 years, and the highest incidence rate was reported in a population with more than 70 years of age showing that pancreatic cancer is more common in the elderly population so that the rate of incidence between the sexes increases with age [7]. Age becomes a major determinant of pancreatic cancer incidence because most patients are diagnosed with pancreatic cancer at the age of over 50 years with the undiagnosed common age of seven to eight decades.

The study was discontinued by taking medical records due to the lack of patient data collected during 20092016, making it difficult to describe clinical data for pancreatic cancer patients such as the type and stage of pancreatic cancer. Histopathological data were also not found in cases of pancreatic cancer because most of the examinations carried out were in the form of radiological examinations as well as medical record data on cases of pancreatic cancer in 2018. 


\section{CONCLUSIONS}

The total pancreatic cancer cases recorded in Dr. Soedarso Hospital Pontianak from January 2009 to December 2018 are 79 with the mean incidence of 7.9 cases per year. Men dominate cases of pancreatic cancer at Dr. Soedarso Hospital Pontianak from 2009 to 2018 by $63.3 \%$, and $67.1 \%$ occurred in patients with the age range of 45-64 years. This study has many data limitations, so it requires development. Further study of the clinical characteristics and analysis of risk factors in patients with pancreatic cancer needs to be done to support preventive strategy development.

\section{DECLARATIONS}

\section{Competing of Interest}

The authors declare no competing interest in this study.

\section{Ethics Approval}

This research had received permission from the Health Promotion Section Hospital through the approval of the Education and Research Section of Dr. Soedarso Hospital with letter number 070/3954/RSDS/PGB-b/2019.

\section{Acknowledgement}

The authors wish to thank the Medicine Faculty of Tanjungpura University and Dr. Soedarso Hospital Pontianak for the chance that gave to the authors. The authors also thank our parents, lecturer, and friends for all the lovely support.

\section{REFERENCES}

1. Kumar V, Abbas AK, Aster JC. Robbins basic pathology. 9th ed. Pennsylvania: Elsevier; 2012.

2. Tortora, Gerard J, Derrickson B. Principles of anatomy and physiology. 12th ed. New Jersey: Wiley; 2009.

3. Hidalgo $\mathrm{M}$, Cascinu $\mathrm{S}$, Kleeff J, et al. Addressing the challenges of pancreatic cancer: future directions for improving outcomes. Pancreatology. 2015;15(1):8-18.

4. De La Cruz MS, Young AP, Ruffin MT. Diagnosis and management of pancreatic cancer. Am Fam Physician. 2014;89(8):626-32.

5. World Health Organization. World Cancer Report. 2014.

6. Siegel RL, Miller KD, Jemal A. Cancer statistics. CA Cancer J Clin. 2015;65(1):5-29.

7. Bosetti C, Lucenteforte E, Silverman DT, et al. Cigarette smoking and pancreatic cancer: an analysis from the international pancreatic cancer casecontrol consortium (Panc4). Ann Oncol. 2012;23(10):2773.
8. Wang YT, Gou YW, Jin WW, et al. Association between alcohol intake and the risk of pancreatic cancer: a dose-response meta-analysis of cohort studies. BMC Cancer. 2016;16:212.

9. Davoodi SH, Malek-Shahabi T, Malekshahi-Moghadam A, et al. Obesity as an important risk factor for certain types of cancer. Iran J Cancer Prev. 2013;6(4):186-94.

10. Casari I, Falasca M. Diet and pancreatic cancer prevention. Cancers (Basel). 2015;7(4):2309-17.

11. Bosch de Basea M, Porta M, Alguacil J, et al. Relationships between occupational history and serum concentrations of organochlorine compounds in exocrine pancreatic cancer. Occup Environ Med. 2011; 68: 332-338.

12. Yadav D, Hawes RH, Brand RE, et al. Alcohol consumption, cigarette smoking, and the risk of recurrent acute and chronic pancreatitis. Arch Intern Med. 2009;169(11):1035-45.

13. De Souza A, Irfan K, Masud F, et al. Diabetes type 2 and pancreatic cancer: a history unfolding. JOP. 2016;17(2):144-148.

14. Matsubayashi H, Takaori K, Morizane C, et al. Familial pancreatic cancer: concept, management and issues. World J Gastroenterol. 2017;23(6):935-948.

15. Risch $H A, Y u H, L u ~ L$, et al. ABO blood group, Helicobacter pylori seropositivity, and risk of pancreatic cancer: a case-control study. J Natl Cancer Inst. 2010;102(7):502-5.

16. Bray F, Ferlay J, Soerjomataram I, et al. Global cancer statistics 2018: GLOBOCAN estimates of incidence and mortality worldwide for 36 cancers in 185 countries. CA Cancer J Clin. 2018;68(6):394-424.

17. Departemen Kesehatan Republik Indonesia. Situasi Derajat Kesehatan. Jakarta: Depkes RI. 2009.

18. Lambe M, Eloranta S, Wigertz A, et al. Pancreatic cancer; reporting and long-term survival in Sweden. Acta Oncol. 2011;50(8):1220-7.

19. Rossi S, Baili P, Capocaccia R, et al. The EUROCARE-5 study on cancer survival in Europe 1999-2007: database, quality checks and statistical analysis methods. Eur J Cancer. 2015;51(15):2104-2119.

20. Popescu-vâlceanu $H$, Nan R, Dragut $R$, et al. Pancreatic Cancer : epidemiology and risk factors. Proc Rom Acad. 2015; 17(2):117-124.

21. Oktarina A, Rasya S, Safyudin S. Karakteristik penderita kanker pankreas di instalasi rawat inap RSUP Dr. Mohammad Hoesin Palembang tahun 2009-2013. Majalah Kedokteran Sriwijaya. 2016;47(1):22-30.

22. Fadillah D. Insidensi penyakit kanker di RSUP Dr. Wahidin Sudirohusodo Makassar periode Januari 2015-Juni 2017. [skripsi]. Makassar: Universitas Hasanuddin; 2017. 
23. Fauza D. Hubungan antara kejadian kanker pankreas dengan diabetes mellitus di poli bedah digestif RSUP H. Adam Malik Medan tahun 2011-2013. [thesis]. Meda: Universitas Sumatera Utara; 2018.

24. Wahi MM, Shah N, Schrock CE, et al. Reproductive factors and risk of pancreatic cancer in women: a review of the literature. Ann Epidemiol. 2009;19(2):103-11.

25. McGuigan A, Kelly P, Turkington RC, et al. Pancreatic cancer: a review of clinical diagnosis, epidemiology, treatment and outcomes. World J Gastroenterol. 2018;24(43):4846-4861.

26. Departemen Kesehatan Republik Indonesia. Situasi Derajat Kesehatan. Jakarta: Depkes RI. 2009.

27. Vrieling A, Bueno-de-Mesquita HB, Boshuizen HC, et al. Cigarette smoking, environmental tobacco smoke exposure and pancreatic cancer risk in the European prospective investigation into cancer and nutrition. Int J Cancer. 2010;126(10):2394-403.

28. Pandol SJ, Apte MV, Wilson JS, et al. The burning question: why is smoking a risk factor for pancreatic cancer? Pancreatology. 2012;12(4):344-9.

29. Lee J, Taneja V, Vassallo R. Cigarette smoking and inflammation: cellular and molecular mechanisms. J Dent Res. 2012;91(2):142-9.
30. Gapstur SM, Jacobs EJ, Deka A, et al. Association of alcohol intake with pancreatic cancer mortality in never smokers. Arch Intern Med. 2011;171(5):444-51.

31. Lucenteforte E, La Vecchia C, Silverman D, et al. Alcohol consumption and pancreatic cancer: a pooled analysis in the international pancreatic cancer case-control consortium (PanC4). Ann Oncol. 2012;23(2):374-82.

32. Sadr Azodi O, Orsini N, Andrén-Sandberg $\AA$, et al. Effect of type of alcoholic beverage in causing acute pancreatitis. Br J Surg. 2011;98(11):1609-16.

33. National Cancer Institute. Alcohol and cancer risk. [Internet]. National Cancer Institute at the National Institutes of Health; 2018. [cited 2019 August 14] Available from: http://www.cancer.gov/aboutcancer/causes-prevention/risk/alcohol/alcohol-factsheet

34. Dai MS, Chao TY, Kao WY, et al. Delayed hepatitis B virus reactivation after cessation of preemptive lamivudine in lymphoma patients treated with rituximab plus CHOP. Ann Hematol. 2004;83(12):76974.

35. Yeo W, Chan PK, Chan HL, et al. Hepatitis B virus reactivation during cytotoxic chemotherapyenhanced viral replication precedes overt hepatitis. J Med Virol. 2001;65(3):473-7. 